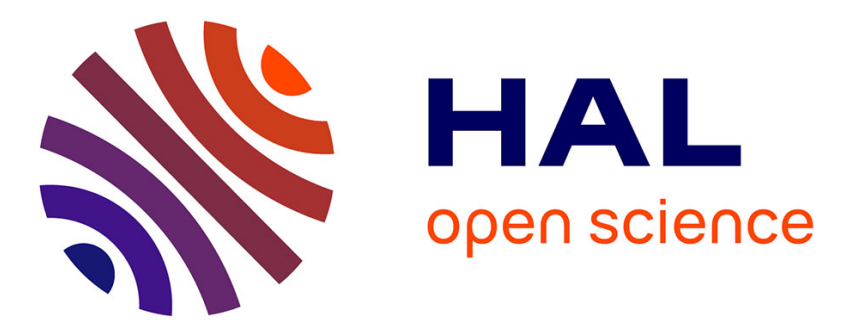

\title{
ICT Unbounded, Social Impact of Bright ICT Adoption
}

\author{
Yogesh K. Dwivedi, Emmanuel Ayaburi, Richard Boateng, John Effah
}

\section{To cite this version:}

Yogesh K. Dwivedi, Emmanuel Ayaburi, Richard Boateng, John Effah. ICT Unbounded, Social Impact of Bright ICT Adoption: IFIP WG 8.6 International Conference on Transfer and Diffusion of IT, TDIT 2019, Accra, Ghana, June 21-22, 2019, Proceedings. Springer International Publishing, AICT-558, 2019, IFIP Advances in Information and Communication Technology, 978-3-030-20670-3. 10.1007/978-3-030-20671-0 . hal-02294677

\section{HAL Id: hal-02294677 \\ https://hal.inria.fr/hal-02294677}

Submitted on 24 Sep 2019

HAL is a multi-disciplinary open access archive for the deposit and dissemination of scientific research documents, whether they are published or not. The documents may come from teaching and research institutions in France or abroad, or from public or private research centers.
L'archive ouverte pluridisciplinaire HAL, est destinée au dépôt et à la diffusion de documents scientifiques de niveau recherche, publiés ou non, émanant des établissements d'enseignement et de recherche français ou étrangers, des laboratoires publics ou privés. 


\section{IFIP Advances in Information and Communication Technology}

\section{Editor-in-Chief}

Kai Rannenberg, Goethe University Frankfurt, Germany

\section{Editorial Board Members}

TC 1 - Foundations of Computer Science

Jacques Sakarovitch, Télécom ParisTech, France

TC 2 - Software: Theory and Practice

Michael Goedicke, University of Duisburg-Essen, Germany

TC 3 - Education

Arthur Tatnall, Victoria University, Melbourne, Australia

TC 5 - Information Technology Applications

Erich J. Neuhold, University of Vienna, Austria

TC 6 - Communication Systems

Aiko Pras, University of Twente, Enschede, The Netherlands

TC 7 - System Modeling and Optimization

Fredi Tröltzsch, TU Berlin, Germany

TC 8 - Information Systems

Jan Pries-Heje, Roskilde University, Denmark

TC 9 - ICT and Society

David Kreps, University of Salford, Greater Manchester, UK

TC 10 - Computer Systems Technology

Ricardo Reis, Federal University of Rio Grande do Sul, Porto Alegre, Brazil

TC 11 - Security and Privacy Protection in Information Processing Systems

Steven Furnell, Plymouth University, UK

TC 12 - Artificial Intelligence

Ulrich Furbach, University of Koblenz-Landau, Germany

TC 13 - Human-Computer Interaction

Marco Winckler, University of Nice Sophia Antipolis, France

TC 14 - Entertainment Computing

Rainer Malaka, University of Bremen, Germany 


\section{IFIP - The International Federation for Information Processing}

IFIP was founded in 1960 under the auspices of UNESCO, following the first World Computer Congress held in Paris the previous year. A federation for societies working in information processing, IFIP's aim is two-fold: to support information processing in the countries of its members and to encourage technology transfer to developing nations. As its mission statement clearly states:

IFIP is the global non-profit federation of societies of ICT professionals that aims at achieving a worldwide professional and socially responsible development and application of information and communication technologies.

IFIP is a non-profit-making organization, run almost solely by 2500 volunteers. It operates through a number of technical committees and working groups, which organize events and publications. IFIP's events range from large international open conferences to working conferences and local seminars.

The flagship event is the IFIP World Computer Congress, at which both invited and contributed papers are presented. Contributed papers are rigorously refereed and the rejection rate is high.

As with the Congress, participation in the open conferences is open to all and papers may be invited or submitted. Again, submitted papers are stringently refereed.

The working conferences are structured differently. They are usually run by a working group and attendance is generally smaller and occasionally by invitation only. Their purpose is to create an atmosphere conducive to innovation and development. Refereeing is also rigorous and papers are subjected to extensive group discussion.

Publications arising from IFIP events vary. The papers presented at the IFIP World Computer Congress and at open conferences are published as conference proceedings, while the results of the working conferences are often published as collections of selected and edited papers.

IFIP distinguishes three types of institutional membership: Country Representative Members, Members at Large, and Associate Members. The type of organization that can apply for membership is a wide variety and includes national or international societies of individual computer scientists/ICT professionals, associations or federations of such societies, government institutions/government related organizations, national or international research institutes or consortia, universities, academies of sciences, companies, national or international associations or federations of companies.

More information about this series at http://www.springer.com/series/6102 
Yogesh Dwivedi · Emmanuel Ayaburi ·

Richard Boateng · John Effah (Eds.)

\section{ICT Unbounded, Social Impact of \\ Bright ICT Adoption}

IFIP WG 8.6 International Conference on Transfer and Diffusion of IT, TDIT 2019 Accra, Ghana, June 21-22, 2019

Proceedings 


\section{Editors}

Yogesh Dwivedi
Swansea University
Swansea, UK

Richard Boateng

University of Ghana

Accra, Ghana

\author{
Emmanuel Ayaburi \\ University of Texas Rio Grande Valley \\ Edinburg, TX, USA
}

John Effah

University of Ghana

Accra, Ghana

\author{
ISSN 1868-4238 ISSN 1868-422X (electronic) \\ IFIP Advances in Information and Communication Technology \\ ISBN 978-3-030-20670-3 ISBN 978-3-030-20671-0 (eBook) \\ https://doi.org/10.1007/978-3-030-20671-0
}

(C) IFIP International Federation for Information Processing 2019

This work is subject to copyright. All rights are reserved by the Publisher, whether the whole or part of the material is concerned, specifically the rights of translation, reprinting, reuse of illustrations, recitation, broadcasting, reproduction on microfilms or in any other physical way, and transmission or information storage and retrieval, electronic adaptation, computer software, or by similar or dissimilar methodology now known or hereafter developed.

The use of general descriptive names, registered names, trademarks, service marks, etc. in this publication does not imply, even in the absence of a specific statement, that such names are exempt from the relevant protective laws and regulations and therefore free for general use.

The publisher, the authors and the editors are safe to assume that the advice and information in this book are believed to be true and accurate at the date of publication. Neither the publisher nor the authors or the editors give a warranty, expressed or implied, with respect to the material contained herein or for any errors or omissions that may have been made. The publisher remains neutral with regard to jurisdictional claims in published maps and institutional affiliations.

This Springer imprint is published by the registered company Springer Nature Switzerland AG The registered company address is: Gewerbestrasse 11, 6330 Cham, Switzerland 


\section{Preface}

The main goal of IFIP Working Group $8.6^{1}$ is understanding the development, diffusion, adoption, and implementation of technology, systems, as well as the resulting information that is produced and how it is used. The 2019 IFIP Working Group 8.6 conference was held in Accra, Ghana, and was hosted by the University of Ghana. We are very grateful to the university and its members, especially the School of Business, for generously offering conference facilities at no charge.

The 2019 Conference of the IFIP WG8.6 focused on "Bright Information and Communication Technologies (ICT)." This proceedings volume examines people and organizational issues with the design, implementation, and use of Bright ICT in relation to the development of society. Bright ICT, a 2015 initiative of the Association of Information Systems introduced by Prof J. K. Lee, refers to the grand vision of a bright society enabled by ICT (Lee, 2015). The concept of Bright ICT entails the development of relevant technologies, business models, public policies, social norms, international agreements, metrics of measuring national progress, and preventing undesirable activities on the Internet. Bright ICT research involves taking a holistic view in the design of an ICT-enabled future society (Lee, 2015). The papers included in this volume present research and business models that offer opportunities to achieve the Bright ICT vision within the context of developing, transitioning, and emerging economies.

The adoption and diffusion of information technology (Dwivedi et al. 2017) have seen many dark sides such as the emergence of cyber criminals and the unethical use of ICT (Lee and Fedorowicz, 2018). This major twist from the good intention of adopting technology and Web-based services has affected developing and less developed economies. Organizations in these economies can benefit from the innovative use of ICT and the diffusion of mobile technologies within their customer base (Andoh-Baidoo, 2016). However, the less-developed economies generally lack the resources and capabilities needed to fight the negative effect of ICT (Dwivedi et al. 2015; Kamal et al. 2009). Research on ICT in the context of these economies that focuses on people and organizations is still scarce. The papers presented in the proceedings focus on proposing and testing theoretical models to address different ICT research problems.

The conference offered an opportunity for the presentation of research on the progress made in this endeavor and an opportunity to understand how the knowledge accumulated thus far translates into societal benefit. We particularly welcomed research that questioned how emerging technologies are adopted and appropriated in organizations and everyday life and the impact they are having. However, we also remained open and committed to the wider theme of the IFIP 8.6 working group. All papers were double-blind reviewed by at least two expert reviewers. We followed a constructive

1 http://ifipwg86.wikidot.com/. 
reviewing process. This resulted in 30 full-length papers and four short papers from a total of 72 papers submitted. In addition, 47 doctoral consortium projects were accepted to be presented at the pre-conference doctoral consortium and they do not appear in the proceedings. The acceptance rate of the papers in the proceedings is nearly $47 \%$. We appreciate the members of the Program Committee for helping in the reviewing and selection process and providing their comments to us in a timely manner, thereby making this event possible.

This book is organized in five parts to reflect the themes of the papers. Part I includes papers that address technology adoption, diffusion, and ubiquitous computing in government and developing countries. Part II presents papers on big data and business intelligence implementation at the firm and country levels. Part III includes papers on smart cities involving different smart technologies ranging from analytics to smart home devices. Part IV presents papers that discuss security, privacy, ethics, and misinformation. The final part includes papers that examine different concepts in social media and open computing. The papers offer insightful contributions in the context of developing economies by providing recommendations that help mitigate the dark side of the Internet and realize the potential of existing and emerging technologies.

Our sincere thanks go to all the authors, reviewers, attendees, Program Committee members, program chairs, and the University of Ghana staff who all made the 2019 IFIP WG 8.6 conference a success. Special thanks to Prof. H. R. Rao and Prof. George Kasper for helping to bring this conference to Ghana.

April 2014

Yogesh Dwivedi Emmanuel Ayaburi

Richard Boateng

John Effah

\section{References}

Andoh-Baidoo, F.K. (2016) Organizational Information and Communication Technologies for Development, Information Technology for Development, 22:2, 193-204.

Dwivedi, Y. K., Rana, N. P., Jeyaraj, A., Clement, M., \& Williams, M. D. (2017). Re-examining the unified theory of acceptance and use of technology (UTAUT): Towards a revised theoretical model. Information Systems Frontiers, 1-16. DoI: https://doi.org/10.1007/s10796-017-9774-y

Dwivedi, Y. K., Wastell, D., Laumer, S., Henriksen, H. Z., Myers, M. D., Bunker, D., ... \& Srivastava, S. C. (2015). Research on information systems failures and successes: Status update and future directions. Information Systems Frontiers, 17(1), 143-157.

Kamal, M., Good, T., \& Qureshi, S. (2009). Development outcomes from IT adoption in microenterprises. In System Sciences, 2009. HICSS'09. 42nd Hawaii International Conference on (pp. 1-10). IEEE. 
Lee, J. K. (2015). Research framework for AIS grand vision of the bright ICT initiative. MIS Quarterly, 39(2).

Lee, J., \& Fedorowicz, J. (2018). Identifying Issues for the Bright ICT Initiative: A Worldwide Delphi Study of IS Journal Editors and Scholars. Communications of the Association for Information Systems: 42, Article 11. DOI: https://doi.org/10. 17705/1CAIS.04211 


\section{Organization}

\section{Conference Chairs}

Francis Kofi Andoh-Baidoo

Emmanuel W. Ayaburi

Richard Boateng

Deborah Bunker

Yogesh K. Dwivedi

George M. Kasper

H. Raghav Rao
University of Texas Rio Grande Valley, USA

University of Texas Rio Grande Valley, USA University of Ghana, Ghana

University of Sydney, Australia

Swansea University, UK

Professor Emeritus, Virginia Commonwealth

University, USA

University of Texas at San Antonio, USA

\section{Program Chairs}

Yogesh K. Dwivedi

Emmanuel W. Ayaburi

Francis Kofi Andoh-Baidoo

John Effah

David Asamoah

\section{Organization Chairs}

Emmanuel W. Ayaburi

John Effah

University of Texas Rio Grande Valley, USA

University of Ghana, Ghana
Swansea University, UK

University of Texas Rio Grande Valley, USA

University of Texas Rio Grande Valley, USA University of Ghana, Ghana

KNUST, Ghana

\section{Doctoral Consortium Chair}

H. Raghav Rao

The University of Texas San Antonio, USA

\section{Conference Administrator}

School of Business, University of Ghana, Ghana

\section{Keynote Speakers}

H. Raghav Rao

Jae Kyu Lee 
Current Officers of IFIP WG8.6: Transfer and Diffusion of IT

\section{Chair}

Yogesh K. Dwivedi

Swansea University, UK

\section{Vice-chairs}

Amany Elbanna

Royal Holloway University, UK

Helle Zinner Henriksen

Copenhagen Business School, UK

Secretary

Banita Lal

University of Bedfordshire, UK

Treasurer and Membership

David Wastell

Nottingham University Business School, UK 


\section{Contents}

\section{Technology Adoption, Diffusion and Ubiquitous Computing}

Neuroethics of Augmenting Human Memory Using Wearable Pervasive and Ubiquitous Technologies . . . . . . . . . . . . . . . . . .

Kuribachew Gizaw

LabNet: An Image Repository for Virtual Science Laboratories. . . . . . . . . . . Ifeoluwatayo A. Ige and Bolanle F. Oladejo

Mobile App Stores from the User's Perspective . . . . . . . . . . . . . . . .

Abdullah M. Baabdullah, Ali Abdallah Alalwan, Nripendra P. Rana, Ata Al Shraah, Hatice Kizgin, and Pushp P. Patil

The Adoption and Diffusion of Wearables . . . . . . . . . . . . . .

Ton A. M. Spil, Björn Kijl, and Vincent Romijnders

Technical Support: Towards Mitigating Effects of Computer Anxiety on Acceptance of E-Assessment Amongst University Students in Sub Saharan African Countries . . . . . . . . . . . . . . . . . . . .

Kayode I. Adenuga, Victor W. Mbarika, and Zacchaeus $O$. Omogbadegun

ICT Laws, Uncertainty Avoidance, and ICT Diffusion:

Insights from Cross-Country Data . . . . . . . . . . . . . . . . . .

Anupriya Khan and Satish Krishnan

Internet-Based Channel Orientation for Domesticated Services Firm:

Some Drivers and Consequences. . . . . . . . . . . . . . . . . . . . .

Michael Adu Kwarteng, Abdul Bashiru Jibril, Fortune Nwaiwu, Michal Pilik, and Maged Ali

Understanding the Factors Influencing Mobile Commerce Adoption by Traders in Developing Countries: Evidence from Ghana . . . . . . . . . . . . . Mercy Kwofie and Joseph Kwame Adjei

A Literature Review of Mobile Payments in Sub-Saharan Africa. . . . . . . . . . Richard Boateng and Maame Yaa Prempeh Sarpong

Explaining Technology Adoption with Financial Motivation. . . . . . . . . . Joseph Budu, Jefferson Seneadza, Edward Entee, Michael Fosu, Bismark Tei Asare, and Charles Mensah 
A Comparative Study of Business-to-Government Information Sharing

Arrangements for Tax Reporting. . . . . . . . . . . . . . . . .

Rizky Amalia Kurnia, Dhata Praditya, and Marijn Janssen

Brightening Physical University Admission Through Digital Process

Virtualization: An Action Case Study in Ghana ................

John Effah

Use of Digital-Physical Security System in a Developing Country's Port:

A Case Study of Ghana . . . . . . . . . . . . . . . . . . . . . . . . . .

Fred Amankwah-Sarfo

Understanding the Adoption and Use of E-tail Websites:

An Empirical Analysis Based on the Revised UTAUT2 Model

Using Risk and Trust Factors . . . . . . . . . . . . . . . . . . . . .

Kayode Odusanya, Olu Aluko, and Banita Lal

Theoretical Framework for Digital Payments in Rural India:

Integrating UTAUT and Empowerment Theory .

Manisha Sharma and Sujeet K. Sharma

\section{Big Data and Business Intelligence}

Impact of Business Intelligence on Firm's Performance in Cameroon . . . . . . Varelle Fossi Maffock, Samuel Fosso Wamba, and Jean Robert Kala Kamdjoug

Challenges of Identifying and Utilizing Big Data Analytics

in a Resource-Constrained Environment: In the Case of Ethiopia . . . . . . . . .

Tigabu Dagne Akal, Tibebe Beshah, Stefan Sackmann, and Solomon Negash

Understanding Public Sector Enterprise Resource Planning System

Implementation in Developing Countries: A Literature Review . . . . . . . . . . .

David Mpanga

A Framework for Cloud ERP System Implementation in Developing

Countries: Learning from Lower Local Governments in Uganda . . . . . . . . . .

David Mpanga and Amany Elbanna

Effect of Inter-Organizational Systems Use on Supply Chain Capabilities and Performance ..........................

David Asamoah, Benjamin Agyei-Owusu, Francis Kofi Andoh-Baidoo, and Emmanuel Ayaburi 


\section{Smart Cities}

Role of Smart Cities in Creating Sustainable Cities and Communities:

A Systematic Literature Review . . . . . . . . . . . . . . . . . .

Elvira Ismagiloiva, Laurie Hughes, Nripendra Rana,

and Yogesh Dwivedi

A Bibliometric Analysis and Research Agenda on Smart Cities . . . . . . . . .

Samuel Fosso Wamba and Maciel M. Queiroz

\section{Security, Privacy, Ethics and Misinformation}

Authenticating Fake News: An Empirical Study in India . . . . . . . . . . . .

Gautam Prakash, Ravinder Kumar Verma, P. Vigneswara Ilavarasan, and Arpan K. Kar

Rumour Veracity Estimation with Deep Learning for Twitter . . . . . . . . . . Jyoti Prakash Singh, Nripendra P. Rana, and Yogesh K. Dwivedi

The Privacy Paradox of Utilizing the Internet of Things and Wi-Fi Tracking

Krystan ten Berg, Ton A. M. Spil, and Robin Effing

The Interplay Between Privacy, Trust and Self-disclosure on Social

Networking Sites. . . . . . . . . . . . . . . . . . . . . . . . . . . . .

Eli Fianu, Kwame Simpe Ofori, Richard Boateng,

and George Oppong Appiagyei Ampong

A Rethink of the Nature and Value of IT Assets - Critical

Realism Approach. . . . . . . . . . . . . . . . . . . . . . . . . .

A. Kayode Adesemowo

Understanding Internet Fraud: Denial of Risk Theory Perspective Martin Offei, Francis Kofi Andoh-Baidoo, Emmanuel Ayaburi, and David Asamoah

Virtual Social Networks as Public Sphere: Relating E-government Maturity,

ICT Laws, and Corruption . . . . . . . . . . . . . . . . . . . . . . . . .

Jithesh Arayankalam and Satish Krishnan

Antecedents of Optimal Information Security Investment:

IT Governance Mechanism and Organizational Digital Maturity . . . . . . . . . .

Samuel Okae, Francis Kofi Andoh-Baidoo, and Emmanuel Ayaburi 


\section{Social Media and Open Computing}

Social Media Presence \& Usage in Indian Business Sector. . . . . . . . . . . . .

Anushruti Vagrani, Jenny John, P. Vigneswara Ilavarasan, and Arpan Kumar Kar

Bright ICT and Unbounded Employment: Typology of Crowdworkers and Their Lived and Envisaged Career Trajectory in Nigeria . . . . . . . . . . . Ayomikun Idowu and Amany Elbanna

The Role of Social Media in Citizen's Political Participation . . . . . . . . . . Abreham Getachew and Tibebe Beshah

Development of Resilient Health Information Infrastructure in Complex, Dynamic and Resource Constrained Health Care Context. . . . . . . . . . . . . Birkinesh Woldeyohannes Lagebo

Influence of Social Media Practices on the Fusion of Strategies

Within Organisations . . . . . . . . . . . . . . . . . . . . . . . Shirumisha Kwayu, Banita Lal, and Mumin Abubakre

Navigating Global Online Market Places

(GOMPs) - An ADR Perspective . . . . . . . . . . . . . . . . . .

Abayomi Baiyere, Thomas Jensen, Louise Fischer, Kalina Staykova, Michael Wessel, and Jonas Hedman

Bright ICT: Social Media Analytics for Society and Crisis Management . . . Deborah Bunker, Stefan Stieglitz, Christian Ehnis, and Anthony Sleigh

Technostress Effect in Consumer Context: The Negative Effect of Following Social Media Influencers. . . . . . . . . . . . . . . . .

Zainah Qasem 